Meta

Journal des traducteurs

Translators' Journal

\title{
Back-Formations in English Word-Formation
}

\section{Garland Cannon et Guy Bailey}

Volume 31, numéro 4, décembre 1986

URI : https://id.erudit.org/iderudit/002197ar

DOI : https://doi.org/10.7202/002197ar

Aller au sommaire du numéro

Éditeur(s)

Les Presses de l'Université de Montréal

ISSN

0026-0452 (imprimé)

1492-1421 (numérique)

Découvrir la revue

Citer cet article

Cannon, G. \& Bailey, G. (1986). Back-Formations in English Word-Formation. Meta, 31(4), 427-438. https://doi.org/10.7202/002197ar d'utilisation que vous pouvez consulter en ligne.

https://apropos.erudit.org/fr/usagers/politique-dutilisation/ 


\section{BACK-FORMATIONS IN ENGLISH WORD-FORMATION}

\section{BACKGROUND}

Among the various word-making processes, back-formation has been of interest to prominent linguists for several centuries (see Stcin's bibliography $1973: 258-259$, which lists 15 sources). Although the process has contributed comparatively few items to the English lexicon (Pennanen 1966) lists just under 800 in his comprehensive study, while they comprise less than $2 \%$ of Algeo's 1981 corpus), back-formation is the subject of a monograph (Pennanen 1966) and five articles (Wittmann 1914, Jespersen 1935, Hall 1956, Pennanen 1975, Mullen 1979). In addition, it is the object of extensive comment not only in grammars and histories of English (e.g., Zandvoort 1962, Strang 1968, Bloomfield and Newmark 1967, Williams 1975), but also in general works on language change (e.g. Honingswald 1960, Jeffers and Lehiste 1979) and linguistic theory (Bloomfield 1933). In spite of this scholarship, linguists are far from a consensus on back-formation. Disagreements about the process primarily involve five issues : the defi- 
nition of back-formation (i.e., what actually constitutes the process), the relation of back-formation to a synchronic grammar, the productivity of the process, the various morphological structures on which back-formation operates, and usage restrictions on the process. In this study we will review the literature on the subject, update and attempt to reconcile differing formulations, and make conclusions on the basis of a unique corpus of 152 contemporary back-formations from three major word-collections of the 1970s and early 1980s that were not available even for Pennanen's monograph.

Although Jespersen (1982) attributes the term back-formation to Sir James Murray (who used the term in the $O E D$ in 1897 in the entry for burgle), Pennanen (1966) notes that the French scholar Émile Egger wrote on "retrograde derivations". During this period, scholars such as Brugmann noted back-formations in almost all of the IndoEuropean languages and in some non-Indo-European languages such as Hungarian. (See Pennanen for a thorough review of this literature; Sturtevant [1961:120] says that back-formations occur in all languages.) Studies devoted to the process exclusively in English, however, are primarily a $20^{\text {th }}$ century development. The early studies of Wittmann (1914) and Bradley (1904) establish two distinct conceptions of back-formation, which, with some modifications, persist to the present. Wittmann's definition is by far the broader. For her, back-formation is synonymous with shortening, with clippings such as brim (f. brimstone) and cab (f. cabbage), as well as with shortenings such as typewrite (f. typewriter), all treated as back-formations. If we accept her definition of the process, back-formation becomes a major source of word-formation in English. Her approach is maintained in the lengthiest study of back-formation in American English (Mencken 1963), where back-formation becomes a synonym for clipping of nouns and in a wide-meshed way even includes "transferred verbs" like sleep in "The house can sleep four people" ; the traditional definition would exclude many of Mencken's examples. In a recent analysis of the general process of shortening, Kreidler suggests that the distinction between back-formation and clipping is not essential (1979: 198).

Bradley's approach is more restrictive. He conceives of back-formation as a special kind of shortening - the formation of a new root through the deletion of what is mistakenly thought to be, but is not, a derivational suffix, with a new suffix sometimes added as well. Thus according to his definition, deletion of what is thought to be an inflection is not a back-formation. Bloomfield (1933) preserves Bradley's approach, with some modifications. Bloomfield emphasizes the analogical nature of the process, as does Williams (1975), pointing out that "the most favorable ground for analogic forms is a derivative type which bears some clear-cut meaning" (p. 412). Thus the seeming agentive-suffix -er, which has a clear-cut meaning and is quite productive in Modern English, is frequently lost in back-formations. In addition, Bloomfield notes that endings taken to be inflections can also be lost in back-formation, and that the process affects simple as well as compound forms. Thus the back-formed riddle (from the ME singular redels) is the creation of a new singular on the pattern of stone: stones. His formulation that many English verbs were the result of back-formation from nouns with -tion helped lead to Lee's documentation of the process in Old English, including verbs back-formed from adjectives with -ed or -od that mean 'to give to, use on, equip with, expose to, pattern after', as well as to Lee's correction (1948) that verbs with -ate beginning in the fourteenth century were usually the result of functional shift rather than of backformation. (Analytically, it is easy to differentiate the two processes, as functional shift permits no change in form when an item also begins to be used as a different form-class ; see Cannon 1985, and Pennanen 1975.) Strang (1968) goes so far as to suggest that the analogical aspects of back-formation are more important than the actual shortening : "it might, in terms of surface forms, be thought of as involving the subtraction of a mor- 
pheme, but it can better be interpreted as a means of completing a proportion" (1968: 231). Bradley's conception of back-formation also underlies the most ambitious work on the process - Pennanen (1966). This monograph emphasizes the "regressive direction" of the process plus the role of analogy, but adds a new criterion : a back-formation must "display such a change in its word-form as to be looked upon as a new word" (p. 34). Thus pea (f. pease) is not a back-formation, according to Pennanen.

The most significant modifications of Bradley's approach were made by Jespersen $(1923,1935,1942,1982)$. Jespersen also emphasizes the analogical aspects of backformation, but he points out that the process presupposes a prior reanalysis of the linguistic form in question :

the characteristic trait of back formation in contrast to other shortenings is that it always presupposes an analysis of the word different from the original or historical way of building it up, a re-interpretation, or "metanalysis" (1942: 337).

Elsewhere he suggests that the back-formation "probably occurs with the first acquisition of the word" (1923: 178) and results from transmission to new groups of speakers, who reanalyze the form. His emphasis on reanalysis has had special appeal for work on language change, such as Hœningswald (1960) and Jeffers and Lehiste (1979). The latter emphasize that back-formation is "an analogical process involving reinterpretation of the morphological structure of the word" (p. 174), and indicate that this kind of reanalysis has a "profound effect on the morphological and morphosyntactic system of a language" (p. 66). Adams (1973) expands the concept of reanalysis to distinguish backformed simplexes from back-formed compounds. In a simplex such as beggar, a reinterpretation of the source word has taken place, while in a compound such as globe-trot, the constituent structure of the compound has been reanalyzed (p. 105ff.).

Two other important works on word-formation in Modern English, Marchand (1969) and Bauer (1983), follow Jespersen in stressing the reinterpretative nature of back-formation ; but they differ remarkably in their assessment of the role of the process in a grammar. Marchand says that

backderivation ... has diachronic relevance only. That peddle $\mathrm{vb}$. is derived from peddler sb. through reinterpretation is of historical interest. However, for synchronic analysis the equation is peddle : peddler $=$ write $:$ writer, which means that the diachronic process of backderivation does not affect the derivative correlation for present-day speakers who do not feel any difference $(1969: 3)$.

Bauer, on the other hand, notes that there must have been synchronic processes which allowed the analogy and that "back-formation must be allowed for in a synchronic grammar if it is still a current method of forming lexemes" (1983: 64). Mullen (1979) takes no stand in the matter, concentrating in his theoretical article on the fitting of back-formations into the rules of generative grammar; however, as we will see, his 13 patterns constitute only a fourth of ours, which are probably too numerous and varied to fit into his generative-rule framework.

The resolution to this controversy involves two other issues : (1) the productivity of the process, and (2) the morphological structures that permit back-formation. Bryant (1962 : 258), like several other scholars, asserts that it has given English only "a handful of new words". The relative paucity of examples in Pennanen's 1966 historical study (by comparison with highly productive word-formation processes like noun compounds) might lead us to conclude that the process is proportionately not very productive; but as Pennanen points out, a simple tally is misleading. Well over half of his examples occur after 1800 , and "it is only since the 19th century that [back-formation] has become 
really productive as a pattern of word-formation" (p. 87). In fact, his 227 instances from the first half of the $20^{\text {th }}$ century represent more than twice the total of any century before the $19^{\text {th }}$. He goes so far as to conclude that

the steep rise in the incidence of back-formation during the $19^{\text {th }}$ and the present century is of such a nature as to be regarded as one of the characteristics of modern word-making (p. 90).

The percentage of items in our back-formation category, in contrast to those in the other 20 categories in the total corpus, will permit us to evaluate this conclusion. Moreover, if back-formation is an important method of word-formation in English today, then surely it, like other word-forming processes, must be accounted for in a synchronic grammar.

Whatever the productivity of the process, many scholars have asserted that backformation operates on only a limited number of morphological structures, though our more modern data will exhibit dozens of patterns that scholars have not described and may sometimes be new. Robertson and Cassidy (1954) point to deletion of a seeming agentive-suffix as the most typical variety of back-formation, while Marckwardt (1958) points to -ation as the ending most often affected. Kiparsky (1974:271) asserts that back-formation from compound nouns is a major source of new verbs in English. Pennanen classifies the back-formations in his corpus into six categories (1966:44-86) :

Type I - A verb back-formed from what is believed to be or really is an agent or instrument noun (with deletion of an -er, -ar, or -or).

Type II - A verb back-formed from what is believed to be or really is an action noun (with deletion of an -ing, -a, -age, -ance, -ence, -ard, -ation, -ene, -fication, -iasm, -ice, -(t)ion, -(s)ion, -ision, -ism, -ive, -ment, -our, -sis, -um, -ure, or -y).

Type III - A verb back-formed from an adjectival word taken to be a derivative from the verb (with deletion of an -ing or -en).

Type IV - A noun back-formed from an adjective taken to be a derivative from it (with deletion of an -en, -al, -ic, -ish, -ous, or $-y$ ).

Type $\mathbf{V}$ - An adjective back-formed from a noun, adjective, or adverb whose basic word it is supposed to be (with deletion of an -ience, -ly, -ness, or in-).

Type VI - 'Primary' substantive back-formed from what is taken to be its derivative (with deletion of -age, -ary, -ation, -er, $-y$, or re-).

Pennanen concludes that the first three types are far more common than the last three. In spite of the breadth of his coverage, neither his categories nor his list of would-be affixes includes all of the possibilities in English. His definition of back-formation excludes the deletion of what are taken to be plurals, and his categories do not provide for back-formations from proper names (as when beg was derived from the French name Beghard). Indeed, scholars have overlooked names as sources for back-formations. While his patterns provide a useful starting-point, they need considerable revision, as our corpus will demonstrate.

Finally, numerous scholars have suggested that back-formation is restricted regionally and socially. Pennanen (1966), Nist (1966), and Mencken (1963) assert that the process is more common in the United States than in Britain. Adams (1973), Marchand (1957, 1969), and Robertson and Cassidy (1954), among others, suggest that backformations are more characteristic of informal than formal usage, but without regional confinement. Gordon (1972: 20) has noted the frequent substandard label on burgle from burglar, and the general suspicion of enthuse(d) and complected from enthusiasm and complectioned, respectively, among other examples "of various levels of respectability". Stevick (1968: 255) also raises the question of whether even the fully established 
back-formations "have the blessing of 'correctness' or not". Copperud (1970), however, generalizes that the items may be objectionable only when new and recognizable as back-formations and lose their stigma as they move into standard usage. Our data will provide empirical evidence as to possible usage restrictions, since the items are carefully labeled when the lexicographers have discovered reservations about their status.

Noting that back-formations occur in all but the most formal usage, Hall (1956) stresses the often ephemeral nature of oral back-formations, collecting and recording a valuable corpus with comparatively little effort (no items of which appear in our corpus), and urging the systematic recording of such items before they vanish. His data are particularly interesting, in that they partly derive from speech rather than writing, and thus seem to be unique. As his limited patterns do not differ from those appearing in our corpus, his oral and some of our written back-formations are identical in patterns. Nor do Russell's 111 noun-incorporating written verbs (1956: 209-212, 284-286), extracted from Russell's files after stimulation by Hall's provocative article, appear in our data, though 37 (exactly one-third) did achieve recording in Webster's Third New International Dictionary (1961). So most of these were apparently nonce forms that were coined and then disappeared.

\section{THE DATA}

Our corpus of 152 recent back-formations comes from three major dictionaries that record 13805 different new items and new meanings of old items in English since the publication of Webster's Third New International Dictionary of the English Language (1961). These are The Barnhart Dictionary of New English since 1963 (1973 hereafter, First Barnhart). The Second Barnhart Dictionary of New English (1980), and Merriam's 9000 Words (1983), which is a hardcover collection of the entries in the Addenda Sections added every five years to the reprints of Webster's Third. As we now describe the 152 items, we will make comparisons with scholars' generalizations about usually earlier back-formations (and sometimes what have loosely been so termed but will actually be excluded from the definition that we will develop), thus casting light on historical change in English. We will note relevant aspects like the process itself, form class, structures, borrowings naturalized since the arbitrarily chosen date of 1825 , stylistic and regional labels, meanings, onomastic items, and duplicated recording in both 9000 Words and a Barnhart dictionary, if not in one of the three published volumes of the new Supplement of the $O E D$ (1972-82 - hereafter, $O E D S$ ) for $A-S c$. (There is no duplication between First Barnhart and Second Barnhart.) The findings will throw light on the role, novelty of patterns, and other aspects of back-formations in current written English, which may sometimes also hold true for the English language itself (a necessary caution in view of the paucity of dictionaries of oral forms). As this study is a spinoff from Historical Change and English Word-Formation (Cannon, forthcoming), the overall findings will provide perspective for our conclusions about back-formations e.g., comparing their percentages to those of functional shifts and initial affixations (see Cannon 1979), to the percentages of status labels and duplication in the $O E D S$, and other interesting differences. Our data are listed in the Appendix.

Our 152 items were formed by 145 reductions, plus seven reductions accompanied by terminal addition. Thus we establish the overwhelming dominance of reduction as the principal process, though we have arbitrarily disregarded about two dozen instances of an added "silent $-e$ ", where a noun like decapacitation produces the verb decapacitate, as opposed to the verb attrit from attrition. All but four of the 145 reductions have been terminal. The four comprise three initial reductions (n. eptitude f. ineptitude, and adjs. flappable f. unflappable, plus ept $\mathrm{f}$. inept), together with one medial loss (v. lay-back f. adj. laid-back). The loss of -er, -ing, or -ion from nouns accounts for 70 new verbs (e.g. 
knuckle-walk f. knuckle-walker, blockbust f. blockbusting, echolocate f. echolocation). The seven items formed from reduction plus addition comprise four adjectives from nouns where -en is added (contact-inhibited f. contact inhibition, cybernated f. cybernation, deafferented $\mathrm{f}$. deafferentation, hominized f. hominization) and three nouns (martial artist $\mathrm{f}$. martial arts, paraphysics $\mathrm{f}$. adj. paraphysical, prediabetes $\mathrm{f}$. adj. prediabetic). As we will see, the reduction is almost always only 1-2 syllables and constitutes a minimum part of the source, so that a term like clipping (as in traditional examples of bus $\mathrm{f}$. omnibus, and dorm f. dormitory) cannot be a synonym for back-formation.

The form classes of these items consist of 97 verbs, 41 nouns, and 14 adjectives. This finding significantly varies from Pennanen (1966: 149), who concludes that English back-formation in recent years "has mainly yielded composite verbs, but only a few sporadic substantives and adjectives". Except that 227 of his data come from the first half of the $20^{\text {th }}$ century, we might merely surmise that ours are later data or else that our back-formed nouns and perhaps adjectives are suddenly rapidly increasing at the expense of what has traditionally been back-formed verbs (which are perhaps in less favor). As we now analyze our 97 verbs, we immediately see that three centuries-old patterns are still very common. First, 38 nouns have lost -ion (eutrophicate f. eutrophication), usually in a straightforward manner except in a few cases of assimilation/dissimilation (desorb $\mathrm{f}$. desorption). Second, 11 of what usually appear to be agent or instrument nouns have lost -er (overachieve f. overachiever). Marchand (1969: 391-395) names these two patterns as the major kinds of back-formations, but relegates as an "isolated pair" the action nouns which lose -ing and produce 21 of our verbs (also see Marchand 1957). Hall's 48 examples (1956) utilize these three old patterns.

Besides these three dominant patterns, which produce 70 of the back-formed verbs, we find 16 other patterns that scholars have seldom or never described and that produce a scattered 27 verbs. Thus three nouns have lost their -ance or -ence (surveillef. surveillance), two their $-y$ (holograph), and two their -is (eletrophorese f. electrophoresis). Six nouns have lost a varying ending (anticoagulate f. anticoagulant, haberdash f. haberdashery, fellate f. fellation, delir f. delirium, wedel f. Wedelen, one-upman f. oneupmanship); and duke has lost its original -s. Two other verbs from nouns are metrify (f. metrification) and one-up (f. one-upmanship). Eleven verbs come from adjectives. Seven have lost their -en (underdevelop), two their $-y$ (funk), one its -ish (kitten), and one its -ing (gangle).

As all of our 97 verbs do not fit into Pennanen's three verb types (1966), it is difficult to make a comparison. Our verbs come from 86 nouns and 11 adjectives, so that verb back-formation always changes the form class. With some forcing, we can fit 11 verbs into his Type I (loss of -er, -ar, -or), 62 into his Type II (loss of -ance, -ence, -ing, $-(t)$ ion), and one into his Type III (loss of "adjectival" -ing). However, 14 of our 19 patterns are excluded, and several of our Type II classifications do not come from true agent or instrument nouns. Perhaps only 20 of our verbs are excluded if we can force another three into Type I. So our data show that our Type II is more than five times as plentiful as our Type Is, whereas Pennanen's Table I (p. 87) shows that II has 282 items, I has 256, and III has 152 items; also, our Type III has only one item. Of the 22 endings listed in his Type II, our data illustrate only four, so that 18 may no longer be viable or at least do not appear among our source words.

Pennanen's Table I gives him the striking conclusion of a preponderance of $87,3 \%$ Types I-III items, in contrast to his Types IV-VI, whereas only half of our data are Types I-III, really, only Types I-II. When we turn to our 41 nouns, the disparity is revealed just as strikingly, as they exhibit 20 patterns, for a low average of about two items per pattern. Thus the 22 formed from nouns exhibit 14 patterns. Five nouns have 
lost-er (scintiscan); and another eight have lost their individual -ia, -ics, -ion, -ism, -ivist, -ry, -ship, or -um (pedophile, dermatoglyph, sonicate, surreal, construct, concrete poet, grantsman, and capitate, respectively). Eptitude has lost its in-. Among the seeming inflectional losses, two items have lost $-s(\mathrm{alm})$, and another its $-s$ while gaining -ist (martial artist). Four have lost -ing (bioengineer), and one its -ia while gaining -ium (penetralium). Within these varied patterns, we observe that back-formation has anglicised two Latin-type plurals. The 19 nouns formed from adjectives are more regular. Ten have lost their -ic (psychotogen), and five their $-y$ (raunch). Two have lost -al or -ous (paramedical and frugivorous, respectively). Paraphysics has lost -al while gaining -s; and prediabetes its -ic while gaining -es.

Our 14 adjectives further demonstrate that our back-formations come from patterns of reduction that are much more varied than Pennanen (1966), Marchand (1969), and other scholars have described. They come from 11 patterns. Five nouns have lost their individual -er, -ism, -ization, -manship, or -y (teenybop, surreal, autoimmune, one$u$, and complicit, respectively). Two nouns have lost their $-s$ or -ing (double-figure and jawbone, respectively). Four nouns have lost their -ion and added -en (cybernated). Two adjectives have lost their in-or un- (ept and flappable, respectively). Finally, hyper has lost its original root active.

When we try to fit our 41 nouns and 14 adjectives into Pennanen's Types IV-VI, we again find startling differences. We can fit 17 nouns into Type IV (loss of -al, -ic, -ous, or $-y$ from an adjective), which contain no examples of a lost -en or -ish but nonetheless clearly justify this type. They constitute $11 \%$ of our corpus, vs. Pennanen's $8 \%$. We can fit five "substantives" into Type IV (loss of -er from a noun), with no examples of Pennanen's other five lost "affixes". They constitute 3\%, vs. his identical 3\%. However, 19 of our 41 nouns are excluded from his types.

We can fit only two adjectives into Type V (loss of $-y$ from a noun, and loss of infrom an adjective), leaving 12 adjectives unaccommodated and containing no examples of three of his five lost "affixes". Nor is there an example from a source adverb, as in his rape from rapely. Our two examples of Type $\mathrm{V}$ constitute $0,1 \%$ of our corpus, vs. Pennanen's $2 \%$.

\section{CONCLUSIONS}

There seem to be few limits on the kinds of structure that can be back-formed, as long as it is a noun or an adjective. Thus nouns have provided 86 of the 97 verbs, 22 of the 41 nouns, and 11 of the 14 adjectives, with only the back-formed nouns having a substantial percentage from adjectives. The sources were two acronyms, eight simplexes, and 142 composites, comprising 92 affixations (usually initial) and 50 compounds. There were no abbreviations, blends, functional shifts, or any compounds other than nouns. Among the back-formations are six pairs of homonyms that were recorded about the same time, including three noun and verb pairs. Twelve items came from borrowings naturalized since their first known recording no earlier than 1831 . This statistic compares with the $4 \%$ that such naturalized borrowings constitute of the entire corpus (excluding the 1029 new borrowings in it), so that our back-formations are twice as likely to have come from a recent naturalized borrowing than is true for 20 other categories. Our 12 sources are five Latin, three French, three Greek, and German wedel. (We have cited the back-formations, not the original borrowing.) Overall, most of our back-formations come from centuries-old classical loans, primarily Latin.

Hall (1956: 86) has commented on the inconsistent punctuation of his verbs backformed from nouns, and our data verify and extend his observation. Though most of our items are written solidly, like backscatter, we find numerous examples like custom-make, and a few examples like CAT scan. There may be inconsistency even 
within the same pattern, as when backscatter and job-hop have come from their respective -ing forms. Sometimes we find an orthographic change from the source item, as when bedsit comes from bed-sitter, and job-hop from job hopping.

Our items include 11 slang items which have been so labeled by at least Barnhart or Merriam (about 7\%, vs. 6,5\% slang items in the entire corpus). By contrast, the spinoff study of functional shifts (Cannon 1985) reveals that 14\% of that category are slang. One item is labeled as informal. As our back-formations are little more likely to be stylistically tagged than are other items in the entire corpus, we can set at rest the notion that they are very susceptible to stigmatization. Indeed, as they are all so recent, they disprove Copperud's idea (1970) that the objection may come only when an item is new and that the item then gradually loses its social disfavor. Writers (and readers), who are likely to be more conservative than are speakers (and hearers), are apparently ready to accept the items quickly. The 11 slang items are strictly nontechnical and refer to rather ordinary situations.

Seventeen items are labeled as U.S., with three of these also marked as Canadian (glitz, hyper, team-teach). As ten others are tagged as British, there is not much disparity. The total of 27 regional labels is only slightly móre than the $13 \%$ of such labels for the entire corpus. We find such comparisons as these: $11 \%$ of back-formed U.S. items, vs. $12 \%$ of U.S. blends and verb compounds, $14 \%$ acronyms, $15 \%$ free morphemes, and $20 \%$ functional shifts. So the U.S. proportions are higher in such categories, and it seems clear that our back-formations are not at all substantially American or even preponderantly so in contrast to British labels. Our data do not bear out Pennanen's generalization that "the coining of back-formations is at present mainly carried on in America on the various levels of spoken and written usage" (1966: 150), and they have experienced comparatively few usage restrictions. On the other hand, we do find an interesting chronological fact. First Barnhart's back-formations include seven British items, five U.S., and three slang items, whereas Second Barnhart's include three British items, 12 U.S. (three of which are also Canadian), eight slang, and one informal. So our back-formations of the last decade may suggest a trend, while providing further evidence that U.S. English is not automatically Canadian English. There are no purely Canadian back-formations.

The rather small percentage of labels might suggest that our back-formations may often be of a more technical nature or at least of an international quality. The verbs particularly reflect sciences like biology and chemistry, though the total meanings run the gamut and seem to be no more technical (or popular) than the other categories of the entire corpus. So our items are not at all subject-specific or even subject-omissive. Only two items contain names, $v$ s. the $4,2 \%$ onomastic items among the functional shifts, or the $10 \%$ for the entire corpus. The sources include no trademark (trademarks appear among 17 of the 21 categories). There is no evidence that advertising is the (partial) explanation for any of our back-formations. Thirty-three of Merriam's 55 backformations are duplicated in Barnhart, a duplication rate that is not surpassed by any of the other categories, thereby confirming our conclusion that these particular items have a high frequency, at least in writing. Sixteen of the 33 also appear in the OEDS, and 53 of the 152 are recorded in the $O E D S$ and either Barnhart or Merriam. These percentages are not particularly different from those for other categories, but we should remind ourselves that the last volume of the $O E D S$ (for $S e-Z$ ) has not yet appeared.

Finally, we can return to three issues that we have not yet resolved, in the light of our completed analysis. First, we can refine the traditional definition of back-formation. It is a subprocess of shortening, but so different and constrained in certain ways that it must have its own category. There is no mutilation of the root during the back-forming, 
and what is lost in almost every case is $1-2$ syllables not under primary or secondary stress. Back-formation can be clearly delimited from the vague term clipping, where we can seldom use the product to recover the root. What is lost in back-formations are brief sequences, almost always terminal, that resemble a derivational or inflectional affix (usually derivational). Although the general term shortening grossly explains the operation of all but seven of our back-formations on the surface level, it does not specify the underlying process which allows the subtraction of a number of different types of "suffixes" (including apparent inflectional suffixes, as when alms gives $\mathrm{alm}$ ) and allows the infrequent addition of one of a few suffixes. As Jespersen (1942), Adams (1973), and Pennanen (1975) note, back-formation always involves a reinterpretation of the morphological structure of a simplex or compound. While clippings and initialisms both result in a change in the morphological structure of a word, back-formation is itself the consequence of a morphological reanalysis. It is this reanalysis which makes the process an important theoretical issue and a crucial part of a synchronic grammar, perhaps more so than most other word-formation processes.

Most new items are created from existing lexical materials, principally guided by usage patterns which native speakers have confidently intuited (Cannon, forthcoming). These speakers are sometimes led into mistakes by compelling analogical patterns that are all around them in their language, a mental procedure which Mullen (1979: 6) incorporates into an hypothesis: the native speaker knows that many morphologically complex items were formed by adding suffixes to items, and thus deletes a supposed suffix to regain what is supposedly the source word. So a diachronic mistake essentially explains a back-formation, which must be carefully separated from a related category of shortening. Thus contraception: contracept seems to fit into the common pattern of relation: relate, where a demonstrable suffix is deleted. The latter two are clippings, from which back-formations are sometimes differentiated only by the most careful diachronic etymology. That is why scholars like Mencken and even some professional linguists have sometimes confused these two categories of shortenings and have blurred the whole issue by listing as examples of back-formations some items that are not backformations at all. The new chemosensing might be an example. It derives from the sequential loss of -ive in the earlier chemosensitive (which transmits the heart of the meaning), which is then inflected with -ing. Fortunately, our back-formations include only seven items that undergo shortening and also gain a suffix, so that only these superficially resemble the separate category of Shortening + Bound Morpheme(s), into which chemosensing fits. Diachronics usually differentiates such shortenings from backformations (also from the separate categories of shortenings like abbreviations, acronyms, and blends). Our back-formations exhibit a process of usually terminal reduction, in a large variety of patterns.

Second, the analytical process is shown to be mainly diachronic. Yet here the diachronic analysis merges almost imperceptibly into synchronics, as the end product of diachronics. We would be neglecting valuable data if we defined back-formations as being of only historical interest, as Marchand (1969) does. They become a kind of reverse evidence in refining knowledge about the patterns that have a dominant influence in keeping the language current but constantly changing. The large number of backformation patterns, which may well be expanding, has considerable synchronic importance in helping to explain the ways that new and varied items are coming into English in apparently increasing numbers. Any synchronic description of English must take account of the vocabulary, and the way that vocabulary has come into being has a strong linkage to existing items. That is, synchronics includes an understanding of the relationship between a predecessor but still-existing item and its offspring, both of which must 
be tabulated in the total lexicon, as compared to the more purely diachronic relationship between a new item and its dead predecessor. It is the responsibility of the synchronic scholar to differentiate the true derivational relationship between items like relation and relate in a corpus, from the pseudo-derivational relationship between contraception and contracept, where the content features of the back-formed contracept cannot adequately analyze the related old item contraception.

Third, the process may be becoming more productive, as Pennanen's $20^{\text {th }}$ century data would seem to suggest. Even so, our 152 back-formations constitute only $1,1 \%$ of the total corpus. Only a few scattered categories like blends, free morphemes, and verb compounds are smaller. Quantitatively, categories like noun compounds $(26,3 \%)$, new meanings $(15 \%)$, initial affixations $(11,2 \%)$, and terminal affixations $(9,6 \%)$ overshadow back-formations. Even among the seven categories of shortenings, the process is tied with acronyms as the next to smallest (blends are 1\%), ranging up to unabbreviated shortenings $(4,6 \%)$ and abbreviations $(3,4 \%)$. Certainly it is a very old process dating back to late West Saxon; and the 70 items formed from the deletion of -ion, -er, and -ing are both traditional and representative of highly productive patterns. Most of the remaining 47 patterns have produced only a handful of examples. Of the total number of patterns, 20 produce nouns, 19 produce verbs, and 11 produce adjectives. While the category exemplifies the creativity and variability seen in word-formation throughout the entire corpus, it does not seem to portend the addition of large or even largely increasing numbers of new items. Oral back-formations are being continually created, evidently as nonce forms, most of which are used once and almost immediately forgotten. Only one-third of Russell's items (1956) were recorded in Webster's Third. So the rate of actual addition seems to be quite small, as Merriam's 9000 Words (1983) contains only one additional back-formation (v. credential) that is not in Merriam's 1981 Addenda Section. Once the back-formations are admitted to Merriam, they are not dropped. Cannon (1986) shows the rate of attrition in 1971-83 to be 1,5\%, or 111 deletions of previously entered items, which illustrate most of the categories in the entire corpus.

On the other hand, back-formation is utilizing numerous patterns today, including some that scholars have not described, that are considerably more varied in origin than has been previously thought. Some of these patterns are evidently new in English writing, and the numbers of these new or at least previously undescribed patterns are of much greater consequence than the attested productivity of a few old patterns. That is, the sources of recorded back-formations are becoming much wider and more numerous. This type of word formation is a stable, quite varied, and dynamic category of PresentDay English, well deserving the prestigious scholarship that it has stimulated in the last 70 years. If the numbers of patterns continue to expand, back-formation will deserve even more attention, as it is already one of the most dramatically changing wordprocesses.

GaRLAND CANNON AND GUY BAILEY Texas A \& $M$ University, College Station, Texas, USA

APPENDIX: DATA (97 VERBS, 41 NOUNS, 14 ADJECTIVES)*

$\begin{array}{llll}\text { advect } v . & \text { deregulate } & \text { jawbone } & \text { one-upman } \\ \text { anticoagulate } & \text { desorb } & \text { job-hop } & \text { overachieve } \\ \text { attrit } & \text { devolatilize } & \text { kitten } & \text { photo-degrade } \\ \text { back-mutate } & \text { disgrunt } & \text { kneecap } & \text { photodissociate } \\ \text { backscatter } & \text { disinform } & \text { knuckle-walk } & \text { photoismerize } \\ \text { band } & \text { disintermediate } & \text { lase } & \text { plea-bargain } \\ \text { batch process } & \text { dock } & \text { laterize } & \text { renormalize }\end{array}$




\begin{tabular}{|c|c|c|c|}
\hline bedsit & double-deal & lay back & revascularize \\
\hline Bible-thump & duke & level-peg & role-play \\
\hline blockbust & echolocate & loon & rotovate \\
\hline bottle-feed & electrophorese & maladapt & safekeep \\
\hline breathalyse & eutrophicate & mase & soft-land \\
\hline calligraph & evapotranspire & mediocritize & sonicate \\
\hline comparison-shop & fellate & metricate & surveille \\
\hline concord & Finlandize & metrify & team-teach \\
\hline contracept & free-associate & microencapsulate & thermoregulate \\
\hline credential & funk & microminiaturize & tansduce \\
\hline cross multiply & gangle & micropublish & transaminate \\
\hline cost-cut & glycosyllate & mindblow & transfect \\
\hline custom-make & haberdash & mitose & tumesce \\
\hline decapacitate & hang-glide & nidate & underdevelop \\
\hline decriminalize & holograph & nitpick & vasoligate \\
\hline deexcite & house-sit & offput & wedel \\
\hline $\begin{array}{l}\text { delir } \\
\text { deprofessionalize }\end{array}$ & immunosuppress & one-up & 97 zonk \\
\hline ahermatype $\mathrm{n}$. & deep-think & iatrogenesis & plea-bargain \\
\hline alm & dermatoglyph & kudo & psychotogen \\
\hline amphiphile & encephalitogen & lech & raunch \\
\hline bedsit & eptitude & martial artist & scintiscan \\
\hline bioengineer & frugivore & orienteer & sleaze \\
\hline capitate & funk & paramedic & soft-land \\
\hline CAT scan & glitz & paraphysics & sonicate \\
\hline clast & grantsman & pedophile & surreal \\
\hline concrete poet & grunge & penetralium & 41. teratogen \\
\hline construct & hermatype & prediabetes & \\
\hline сryptobiote & hydrotrope & & \\
\hline autoimmune adj. & deafferented & hominized & one-up \\
\hline complicit & double-figure & hyper & surreal \\
\hline contact-inhibited & ept & jawbone & 14 teenybop \\
\hline cybernated & flappable & & \\
\hline
\end{tabular}

Note

*Lehnert (1971) contains 18 of our items: 13 verbs (anticoagulate, bottle-feed, cost-cut, custom-make, funk, kitten, lay back, lase, metrify, transaminate, transduce, underdevelop, and wedel); three nouns (funk, paramedic, prediabetes); and two adjectives (autoimmune, cybernated).

\section{BIBLIOGRAPHY}

ADAMS, V. (1973): An Introduction to Modem English Word-Formation, London, Longmans, $222 \mathrm{p}$

ALGEO, J. (1978): "The Taxonomy of Word-Making", Word 29, pp. 122-131.

ALGEO, J. (1981): "Where Do All the New Words Come From?", American Speech 55, pp. 264-277.

BARNHART, C.L., S. STEINMETZ and R.K. BARNHART (1973): The Barnhart Dictionary of New English since 1963, Bronxville, N.Y., Barnhart/Harper \& Row, 512 p.

BARNHART, C.L., S. STEINMETZ and R.K. BARNHART (1980): The Second Barnhart Dictionary of New English, Bronxville, Barnhart Books, 520 p.

BAUER, L. (1983): English Word-Formation, Cambridge, Cambridge University Press, 305 p.

BLOOMFIELD, L. (1933): Language, New York, Holt, Rinehart and Winston, 564 p.

BLOOMFIELD, M.W. and L. NEWMARK (1967): A Linguistic Introduction to the History of English, New York, Alfred A. Knopf, $375 \mathrm{p}$.

BRADLEY, H. (1904): The Making of English, New York, Macmillan, $245 \mathrm{p}$.

BRYANT, M.M. (1962): Modern English and Its Heritage, $2^{\text {nd }}$ ed., New York, Macmillan, 492 p.

CANNON, G. (1979): "Affixation and Compounding in New Words in Primarily American English", Meta 24-3, septembre, pp. 326-335.

CANNON, G. (1985): "Functional Shift in English", Linguistics 23, pp. 50-69.

CANNON, G. (1986): "Viability: The Death of Recent New Forms in English".

CANNON, G. (Forthcoming): Historical Change and English Word-Formation: Recent Vocabulary, New York, Peter Lang Publishing. 
COPPERUD, R.H. (1970): American Usage: The Consensus, New York, Van Nostrand Reinhold, 292 p. GORDON, J.D. (1972): The English Language: An Historical Introduction, New York, Thomas Y. Crowell, $326 \mathrm{p}$.

HALL, R.A. Jr. (1956): "How We Noun-Incorporate in English", American Speech 31, pp. 83-88.

HOENINGSWALD, H.M. (1960): Language Change and Linguistic Reconstruction, Chicago, University of Chicago Press, 168 p.

JEFFERS, R.J. and I. LEHISTE (1979): Principles and Methods for Historical Linguistics, Cambridge, Mass., MIT Press, $209 \mathrm{p}$.

JESPERSEN, O. (1923): Language: Its Nature, Development, and Origin, New York, W.W. Norton, 448 p.

JESPERSEN, O. (1935): "A Few Back-Formations in English", Englische Studien 70, pp. 117-122.

JESPERSEN, O. (1942): A Modern English Grammar on Historical Principles. Part VI: Morphology, London, Allen and Unwin, $570 \mathrm{p}$.

JESPERSEN, O. (1982): Growth and Structure of the English Language, 10 th ed., Chicago, University of Chicago Press, 244 p.

KIPARSKY, P. (1974): "Remarks on Analogical Change", in J.M. Anderson and C. Jones, ed., Historical Linguistics II: Theory and Description in Phonology, Amsterdam, North Holland Publishing Co., pp. 257-275.

KREIDLER, C. (1979): "Creating New Words by Shortening", Journal of English Linguistics 13, pp. 24-36.

LEE, D. (1948): Functional Change in Early English, Menasha, Wisc., George Banta Publishing Co., 128 p.

LEHNERT, M. (1971): Reverse Dictionary of Present-Day English, Liepzig, VEB Verlag Enzyklopädie, $596 \mathrm{p}$.

MARCHAND, H. (1957): "Compound and Pseudo-Compound Verbs in Present-Day English", American Speech 32, pp. 83-94.

MARCHAND, H. (1963): "On Content as a Criterion of Derivational Relationship with Backderived Words", Indogermanische Forschungen 68, pp. 170-175.

MARCHAND, H. (1969): The Categories and Types of Present-Day English Word-Formation: A SynchronicDiachronic Approach, $2^{\text {nd }}$ ed., Munchen, C.H. Beck'sche Verlagsbuchhandlung, $545 \mathrm{p}$.

MARCKWARDT, A.H. (1958): American English, New York, Oxford University Press, 192 p.

MENCKEN, H.L. (1963): The American Language, $4^{\text {th }}$ ed. and Two Supplements, abridged by R.I. McDavid, Jr., New York, Alfred A. Knopf, 777 p.

MERRIAM, G. \& C. (1983): 9000 Words, Springfield, Mass., G. \& C. Merriam, 218 p.

MULLEN, D. (1979): "Back-Formation in English: Two Approaches to a Theory of Derivational Morphology", Cahiers linguistiques d'Ottawa 7, pp. 1-37.

NIST, J. (1966): A Structural History of English, New York, St. Martin's Press, 426 p.

Oxford English Dictionary: A Supplement (1972-1982): Oxford, Clarendon Press, 3 vols.

PENNANEN, E.V. (1966): Contributions to the Study of Back-Formations in English, Acta Academiae Socialis, ser. A, Vol. 4, Tampere, 172 p.

PENNANEN, E.V. (1975): "What Happens in Back-Formation?", in E. Hordhaugen (ed.), Papers from the Second Scandinavian Conference of Linguistics, Oslo, University of Oslo, pp. 216-229.

ROBERTSON, S. and F.G. CASSIDY (1954): The Development of Modern English, $2^{\text {nd }}$ ed., Englewood Cliffs, N.J., Prentice-Hall, 469 p.

RUSSELL, I.W. (1956): "Among the New Words", American Speech 31, pp. 209-212, 284-286.

STEIN, G. (1973): English Word-Formation over Two Centuries, Tübingen, Tübinger Beiträge zur Linguistik, $356 \mathrm{p}$.

STEVICK, R.D. (1968): English and Its History, Boston, Allyn and Bacon, 339 p.

STRANG, B.M.H. (1968): Modern English Structure, New York, St. Martin's Press, 201 p.

STURTEVANT, E.H. (1961): Linguistic Change: An Introduction to the Historical Study of Language, Chicago, University of Chicago Press, $185 \mathrm{p}$.

WILLIAMS, J.M. (1975): Origins of the English Language, New York, The Free Press, 422 p.

WITTMANN, E. (1914): "Clipped Words: A Study of Back-Formations and Curtailments in Present-Day English", Dialect Notes 4, pp. 115-145.

ZANDVOORT, R.W. (1962): A Handbook of English Grammar, $2^{\text {nd }}$ ed., London, Longmans, 349 p. 